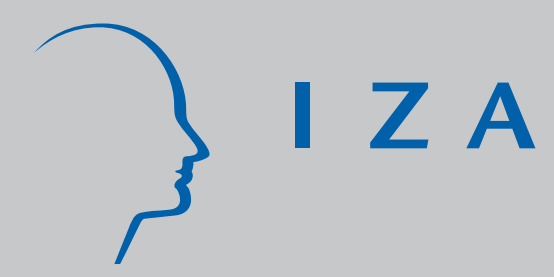

IZA DP No. 3629

When It's (Mostly) the Taking Part that Counts:

The Post-Application Consequences of

Employment Tribunal Claims

Stephen Drinkwater

Paul L. Latreille

K.G. Ben Knight

August 2008 


\title{
When It's (Mostly) the Taking Part that Counts: The Post-Application Consequences of Employment Tribunal Claims
}

\author{
Stephen Drinkwater \\ University of Surrey and IZA
}

Paul L. Latreille

Swansea University

K.G. Ben Knight

University of Warwick

\section{Discussion Paper No. 3629 \\ August 2008}

IZA

P.O. Box 7240

53072 Bonn

Germany

Phone: +49-228-3894-0

Fax: +49-228-3894-180

E-mail: iza@iza.org

Any opinions expressed here are those of the author(s) and not those of IZA. Research published in this series may include views on policy, but the institute itself takes no institutional policy positions.

The Institute for the Study of Labor (IZA) in Bonn is a local and virtual international research center and a place of communication between science, politics and business. IZA is an independent nonprofit organization supported by Deutsche Post World Net. The center is associated with the University of Bonn and offers a stimulating research environment through its international network, workshops and conferences, data service, project support, research visits and doctoral program. IZA engages in (i) original and internationally competitive research in all fields of labor economics, (ii) development of policy concepts, and (iii) dissemination of research results and concepts to the interested public.

IZA Discussion Papers often represent preliminary work and are circulated to encourage discussion. Citation of such a paper should account for its provisional character. A revised version may be available directly from the author. 


\section{ABSTRACT \\ When It's (Mostly) the Taking Part that Counts: The Post-Application Consequences of Employment Tribunal Claims*}

This paper uses the 2003 Survey of Employment Tribunal Applications to examine the postapplication employment consequences for individuals registering complaints to Employment Tribunals following dismissal or redundancy. In examining this issue, we consider a number of pieces of evidence: (i) the probability of finding another job; (ii) the time taken to get a new job and (iii) the pay/status of the new job. It is found that age plays a significant role in aspects (i) and (iii), whilst those who previously held managerial positions generally took longest to get a new job and found it most difficult to achieve a similar level of pay/status in their current jobs. Long-term health problems/disability is associated with significantly worse outcomes on all three measures. Respondents whose cases were dismissed by the tribunals without hearings fared worst in terms of obtaining a new job and the time it took to do so compared with other outcomes. There were, however, fewer differences by outcome in the relative pay/status of the claimant's current job.

JEL Classification: K4, J0

Keywords: employment tribunals, job separations, job search

Corresponding author:

Stephen Drinkwater

Department of Economics

University of Surrey

Guildford

Surrey GU2 7XH

United Kingdom

E-mail: s.drinkwater@surrey.ac.uk

\footnotetext{
* The data used in the paper were collected by BMRB on behalf of the Department of Trade and Industry, the Advisory, Conciliation and Arbitration Service and the Scottish Executive, and were made available by the UK Data Archive at the University of Essex, to whom applications for copies of the data should be made. We are also grateful for comments received from participants at presentations made at the University of Sheffield, the 2007 IERA Conference held at Canterbury Christ Church University and the IIRA HRM Study Group held at the University of Manchester. All views expressed, together with any errors or omissions are the responsibility of the authors alone.
} 


\section{INTRODUCTION}

A relatively large literature has emerged in North America on the impact of job loss on the subsequent employment outcomes of displaced workers. For example, it is has been found that worker displacement leads to lower earnings in both the short run (Farber, 1997) and long run (Jacobsen et al., 1993; Huff Stevens, 1997), higher rates of part-time employment (Farber, 1997; McCall, 1997) and a greater likelihood of further spells of unemployment (Ruhm, 1991). In contrast, there is comparatively little evidence in this area for the UK (exceptions include Casey, 1995; Gregory and Jukes, 2001; and Borland et al., 2002 - see below). However in the US, with a few exceptions which vary by state (Ewing et al., 2005; Autor et al., 2006), most non-unionised workers in the private sector are not covered by statutory unjust discharge protection, but are instead employed on at 'at-will' basis. The same is not true for unionised workers who are typically employed on contracts which provide for arbitration in the event of a disputed separation.

By way of contrast, the UK has a well-established system with adjudication in a whole range of employment-related disputes being the role of Employment Tribunals (ETs). However, little is known in either setting of the consequences of seeking redress for unjust discharge in terms of the post-application employment experiences of grievants ${ }^{1}$. This paper attempts to fill these gaps using UK data from the 2003 Survey of Employment Tribunal Applications

\footnotetext{
${ }^{1}$ There is however some limited descriptive discussion using the same dataset as deployed here in Hayward et al. (2004). See also Tremlett and Banerji (1994).
} 
(SETA 2003) to examine a range of post-tribunal outcomes for workers displaced from their previous job by way of dismissal or redundancy. In particular, we seek to explore the process of job search following a claim $^{2}$ the probability of finding employment, the duration (completed or ongoing) of unemployment and, for those individuals who succeed in finding alternative employment, the quality of job match in terms of both status and pay.

Ascertaining the post-application impact of ET claims is an important issue. Whilst the short-run pecuniary costs of bringing a claim are typically modest, the total cost to the appellant must necessarily also include the psychic costs of the going through the complaints procedure itself, as well as the additional costs in terms of the subsequent impact on employment prospects. Labelling, stigmatisation and scarring are all phenomena of interest in this context. From a policy perspective, the work reported here has important ramifications: if the very act of bringing a case results in substantial costs to the appellant, this may have a significant impact on the propensity to bring cases, such that the observed number of applications (which has risen over time - see Figure 1) actually disguises further latent demand for this form of redress. If this is the situation, it provides some support for the proposal which appeared in the Fairness at Work White Paper that preceded the 1999 Employment Relations Act to abolish the ceilings for compensatory awards in unfair dismissal cases on the grounds that redress should take into account the full and potentially long-term employment consequences indicated above. In the end, and

\footnotetext{
${ }^{2}$ This is perhaps more important in the British context, since re-employment remedies at tribunals are extremely rare (Dickens, et al. 1984; Brown et al. 1997; Knight and Latreille, 2001). In the US arbitration context, see for example Bemmels (1988).
} 
presumably in response to employer representations, the Act merely implemented a substantial increase in the upper limit from around $£ 12,000$ to $£ 50,000$ (now $£ 58,400$ ), although as before, the majority of awards fall significantly short of this.

[Insert Figure 1 about here]

In our analysis we are able to model certain aspects of the job search of individuals who brought ET claims against their former employer, controlling for a variety of applicant, employer and case characteristics. In particular we consider the impact of the way in which the case was resolved: settled before tribunal; withdrawn/dismissed before tribunal; won at tribunal; and lost at tribunal. A priori, we anticipate that the mode of resolution will impinge heavily on appellants' post-application experiences, since this is likely to inform potential employers in their hiring decisions. Such information will likely be revealed by application forms, references from the former employer and employer networks (such as employers' associations, HRM practitioner groups and periodicals, etc.). While we are of the view that bringing a case at all may potentially deter future employers due to the labelling of the applicant as a 'troublemaker', we predict those who lose (or possibly withdraw) a case are likely to find this situation exacerbated.

\footnotetext{
${ }^{3} \mathrm{~A}$ limiting feature of the analysis is that the data relate only to those who brought claims; we are thus unable to compare the consequences for those bringing claims relative to those who did not.
} 


\section{BACKGROUND LITERATURE}

The burgeoning North American literature on worker displacement suggests that job loss can affect the subsequent labour market prospects of an individual in several ways ${ }^{4}$. In terms of employment, Farber (1997) reports that rates of new employment are significantly related to education, gender and ethnicity using US data from the Displaced Worker Survey (DWS). In particular, using a probit model to estimate employment at the survey date, there was found to be a 16 percentage point differential between the employment probability of college and high school graduates, which were also 8 and 13 percentage points lower for females and ethnic minorities respectively. Age variations are also evident, with older displaced workers finding it most difficult to find new employment. For example, individuals aged between 55 and 64 had re-employment rates which were 19 percentage points lower than those aged between 20 and 24. However, job loss still imposes costs on younger workers since Farber (1997) reports that displaced workers aged between 25 and 44 had significantly higher employment rates compared to those in the youngest age category based on some specifications. In addition, Gustafson (1998) reports that young displaced workers experience significantly lower employment probabilities and work shorter hours than those who hadn't experienced job displacement. This suggests that young workers are also significantly affected by job displacement ${ }^{5}$.

\footnotetext{
${ }^{4}$ See Fallick (1996) and Kletzer (1998) for reviews of this literature.

${ }^{5}$ Gregg (2001) examines the impact of youth unemployment on adult unemployment in the UK.
} 
Farber (1997) finds that displaced workers were also more likely to find parttime employment since there was a 6 percentage point difference between the incidence of part-time work between the current and lost job for displaced workers. McCall (1997) reports that amongst displaced Canadian workers who had lost full-time jobs, females stayed unemployed longer and were more likely to find a part-time job when they became re-employed. Further analysis revealed that gender differences in worker characteristics had little explanatory power. Fallick (1996) examines the factors affecting the transition from unemployment to employment for displaced workers. He finds that the industry of the previous job had an impact on job search intensity and reservation wages.

Earnings of displaced workers tend to be significantly lower in the short term. For example, Farber (1997) finds using the DWS that the real difference between pre and post-displacement weekly earnings averaged around 13\% between 1981 and 1995. For some, however, the losses could be of very large orders of magnitude, since around a third of workers reported a loss of at least $25 \%$. In contrast, $30-40 \%$ reported that earnings in their new job represented an increase compared to their previous jobs (Kletzer, 1998). The regression analysis undertaken by Farber (1997) reveals that by far the largest earnings penalties exist for older workers but that they decline with levels of education, with the losses of high school graduates around $7 \%$ greater than comparable college graduates. Relatively small differences were reported by gender and ethnicity. 
Moreover, evidence from the US indicates that the effect of job displacement on earnings is permanent. In particular, Jacobsen et al. (1993) using administrative data consisting of high tenure workers find that long term earnings losses average around 25\% per year. Whilst Huff Stevens (1997), using representative data from the Panel Study of Income Dynamics, reports that the earnings of displaced workers are $9 \%$ lower than expected levels six or more years after the separation. The reasons that have been suggested to explain these reductions in earnings include the loss of firm specific and general human capital, the loss of a potentially good job match and the loss of wage premia. Earnings penalties in the longer term have been found to increase with age, tenure in the previous job and the loss of a union job.

According to Borland et al. (2002), the first UK evidence on unemployment on subsequent earnings comes from Gregory and Jukes (2001) ${ }^{6}$. They match a sample of male unemployment benefit claimants (from the JUVOS database) to wage data from the New Earnings Survey. They report an initial average earnings penalty of over $10 \%$ from losing a job compared to those who remained in their job but that these losses decline over time, falling to around $4 \%$ after 2 years and to around $2 \%$ after this. Earnings penalties are found to vary with age and occupation, with older and those from more skilled occupations most affected. Arulampalam (2001) utilizes the British Household Panel Survey (BHPS) and finds that the long run earnings losses for an

\footnotetext{
${ }^{6}$ An early version of this paper was published in 1997 as a Department for Employment Discussion Paper.
} 
unemployed worker are over $10 \%{ }^{7}$. She also notes that displaced workers as a result of redundancies are less scarred than those losing their jobs for other reasons, such as dismissals or sackings. This may be because workers are given notice of redundancy or that they may find better job matches because of the redundancy payments that they receive. Alternatively, redundancies, by virtue of their typically collective nature, may also be less stigmatising: dismissal is a strong signal typically applied to individuals; collective dismissal in contrast, is not attributed to an individual, but rather to 'bad luck', so the effect is weaker

Possibly of most relevance to our study is the paper by Borland et al. (2002). They use data from the BHPS from 1991 to 1996 to examine the impact of job displacement on a range of labour market outcomes and not only focus on the unemployed but also on those who become economically inactive following a job loss. It is found that the raw earnings loss for displaced workers in their new job compared to their lost job was around 10\%, although this was only around $4 \%$ if the displaced worker found another full-time job. This underestimates the actual loss because of the earnings growth of those who remain in employment, which was around 5\% per annum for their sample. Regression analysis indicates that earnings losses are greater for those who were out of work longer and those aged over 50 . When weekly wages are considered, wage growth was significantly lower for those with longer tenures in their previous jobs and for females.

\footnotetext{
${ }^{7}$ Arulampalam et al. (2001) suggest reasons for differences in the results of Arulampalam (2001) and Gregory and Jukes (2001) including differences in sample sizes, in the definition of unemployment and in the durations of unemployment spells between the two datasets.
} 
Borland et al. (2002) also analyse the factors that impinge on the time it takes to get a new job by computing Kaplan-Meier survival estimates for the time taken to return to work (in months) using a Cox likelihood model. For displaced workers only, they report that those aged over 50 take significantly longer to find a new job, whilst individuals with children and those who had been with their employers for less than a year and who were employed in private services found jobs significantly faster. This was also true for those with non-manual occupations, compared to managers. Gender, marital status and qualifications did not have a significant effect.

It should also be noted that there also exists evidence on the subsequent labour market experiences of UK workers who had been made redundant. For example, Casey (1995) uses data from the Labour Force Survey to examine which characteristics affect the chances of finding a new job. After estimating a logit model, re-employment probabilities were reported to be lower for ethnic minorities and older workers but higher for females and married people. Some characteristics of the individual's previous job were also found to be important. In terms of occupation, semi skilled manuals workers were least likely to have returned to work and those who had professional/managerial and junior managerial/technical jobs the most likely. Re-employment rates were higher for workers who had lost jobs in small establishments and in agriculture, business and financial services. Casey (1995) also reports that having a health problem lowered the chances of older people returning to work. 
In this paper we are only able to examine the short term impacts of job loss since we only have information from the time the interview took place. However, we do have the additional stigma effect of going to a tribunal, in addition to the possible negative effects of job loss itself, while the the difference between dismissal and redundancy can also be explored. Before discussing the data, we next proceed to outline how ETs operate in the UK and also provide a brief review of the main empirical findings on ETs in the UK.

In total, around 100,000 cases are now brought to ETs each year, this number varying over time (Figure 1) in response to both secular factors such as the range of grounds for complaint (jurisdictions), changes in eligibility criteria, etc., and cyclical factors. The single most important jurisdiction is that of unfair dismissal, which currently accounts for around $40 \%$ of claims. Unfair dismissal protection has been enshrined in British employment law since the Industrial Relations Act $1971^{8}$, which introduced "the right not to be dismissed without good reason... an employee has a stake in his [or her] job which cannot be extinguished simply by serving contractual notice" (Harrison, 1990: 187, term in 4 added). Since the legislation took force in 1972, approaching a million such cases have been disposed of. Redundancy payment protection has an even longer pedigree, having first been introduced in the Redundancy Payments Act 1965, since repealed and consolidated in subsequent legislation.

\footnotetext{
${ }^{8}$ Now superseded by subsequent legislation, most notably and inter alia the Employment Relations Act 1999 and the Employment Act 2002 and subsequent Dispute Resolution Regulations (themselves currently subject to consideration by the Gibbons Review).
} 
The relative impact of cyclical and secular influences on the number of (unfair dismissal) applications (demand) is considered by Brown et al. (1997) (see also Burgess et al., 2001), whilst resolution in advance of a full merits tribunal hearing is the subject of Knight and Latreille (2000) (see also Saridakis et al., 2008). Previous econometric work has also considered the determinants of success at tribunal hearings, focusing on grievants' gender (Knight and Latreille, 2001), employer size (Saridakis et al., 2008) and voice regimes (Urwin et al., 2007). There is also more descriptive evidence on the impact of representation on outcomes (Latreille et al., 2004, 2005; Fox and Dix, 2002; Hayward et al., 2004a), the views of representatives concerning the Advisory, Conciliation and Arbitration Service (Acas) (Latreille et al., 2004, 2007), and the differing perceptions of applicants and employers concerning both factual and affective features of cases (Dennison and Corby, 2005; Latreille, 2007a). However, as noted previously, almost nothing is known about the implications of bringing a case in terms of an appellant's post-application employment experiences, and it is this deficiency that the present paper seeks to rectify.

In order to better understand these experiences, it is perhaps useful to set out briefly the institutional framework pertaining at the time to which our data relate (see below) ${ }^{9}$. The process is initiated by an individual or their representative completing an application form setting out the grounds for complaint. At the time of the survey this was known as an IT1, but has since been replaced by a prescribed 11-page form known as an ET1, the change

\footnotetext{
${ }^{9}$ Some of the more important changes since the time of the survey are noted in Latreille et al. (2007).
} 
reflecting the renaming of Industrial Tribunals as Employment Tribunals from October 2004 (we use the current terminology throughout). This is submitted to the Employment Tribunals Service (ETS - now the Tribunals Service (Employment)) who are responsible for the administration of the case, including determining the jurisdiction(s) under which the case will be heard (and also the principal or main jurisdiction in the event there is more than one). The ETS send a copy of the application to the employer (respondent), who must reply on form IT3 (now ET3). Both originating and response forms are sent to Acas, who will attempt to promote conciliation between the parties, thereby avoiding the need for a full merits hearing, something that may in a small proportion of cases also be encouraged by a Pre-Hearing Review where parties with cases deemed to be weak may be warned that costs could be awarded against them in the event of an adverse judgement.

ET cases can result in several possible outcomes. The majority of cases around 60\% in SETA 2003 - are either Acas-conciliated (COT3) or private settlements between the parties, in approximately the ratio 3:1 (Hayward et al. 2004a, Table 8.6; see Latreille, 2007b for a discussion of offers and acceptances). Since settlements generally involve the applicant waiving the right to further prosecute their claim in return for some form of compensation, the latter are only legally binding where a 'compromise agreement' is signed following advice from an independent 'qualified' person such as a lawyer. Such cases should be distinguished from those where the claim is withdrawn without any redress or compensation for the applicant $-16 \%$ of cases in SETA 2003. A further $6 \%$ of cases were dismissed or disposed of without a 
full hearing on technical/procedural grounds ${ }^{10}$. The remaining cases are determined at a full merits tribunal hearing, which will normally involve a three-person panel - a legally qualified chair sitting with two lay members, one each from panels of employee and employer practitioners. The panel may either uphold or reject the claim(s) made by the appellant, and in the former scenario will determine an award to be made by way of redress, the nature (and magnitude of any financial component) of which will depend on the jurisdiction and on the particular circumstances of the case. Costs may also be awarded against the losing party where is considered the party or their representative behaved unreasonably (including applications/defences without a realistic prospect of success).

\section{DATA AND DESCRIPTIVE STATISTICS}

SETA 2003 is the fourth in a series of periodic surveys ${ }^{11}$ looking at the experiences of applicants and employers in ET cases. The latest survey was sponsored by the Department of Trade and Industry (DTI), the ETS and Acas, with funding for a Scottish 'boost' provided by the Scottish Executive so as to facilitate a sample size large enough for separate analysis there ${ }^{12}$. Unlike its predecessors the 2003 survey was designed to cover the full range of jurisdictions rather than focusing on a more tightly prescribed number of claim types. The design, sampling and data collection processes involved in the

\footnotetext{
${ }^{10}$ The most recent reforms provide for pre-screening of cases, with some being applications (and defences) being rejected on the grounds that the relevant forms were not completed correctly.

${ }^{11}$ The earlier surveys took place in 1987, 1992 and 1998 - see Stevens (1988); Banerji et al. (1990); Tremlett and Banerji (1994); and DTI (2002) and Latreille and Latreille (2004) for information concerning the 1998 spin-out survey of representatives in ET cases.

${ }^{12}$ A weighting scheme is available to correct for the over-sampling of cases in Scotland.
} 
2003 survey are described in some detail in the SETA 2003 Technical Report (Hayward et al., 2004b) available from the UK Data Archive. In essence however, SETA 2003 is based on a simple random sample of 4,517 cases completed between March 2002 and March 2003, comprising data from unmatched samples of applicants and employers (of size 2236 and 2281 respectively). Interviewing was undertaken by telephone by BMRB Social Research from October 2003 and January 2004 using Computer Assisted Telephone Interviewing (CATI), and was restricted to cases that were wholly completed at the time of the survey. Our sample is further restricted to applicants who separated for reasons of dismissal or redundancy from the former employer against whom they brought a claim ${ }^{13}$, and also excludes those still working for the same at the time of application.

Table 1 reports the distribution of economic activity for our sample of tribunal applicants by case outcome. Around 55\% of applicants held full-time positions at the time of the interview, the percentage with such jobs varying according to the outcome of the case. Those who withdrew their own cases were most likely to be full-time employees, in part perhaps because the withdrawal of the application was occasioned by the fact they had managed to find a new job, whilst those whose case had been dismissed were the least likely to be so employed. In contrast, part-time employment was more common amongst this latter category, with $15 \%$ of claimants in this group working fewer than 30

\footnotetext{
${ }^{13}$ This should mean that our sample consists solely of displaced workers rather than quits, but some of our sample may have quit their jobs if they believed that the employer breached the terms of their contract (i.e. constructive dismissal cases). The majority (more than two thirds) of claims in the sample involve a claim directly in relation to unfair dismissal or redundancy.
} 
hours a week in their current jobs, compared to $12 \%$ or less amongst the other groups. Self-employment was highest amongst those who had settled after their case had been withdrawn, and for applicants who had lost their tribunal cases. In both instances, the self-employed accounted for more than $17 \%$ of those in employment; higher than the national self-employment rate at the time (Weir, 2003). For the other categories, self-employment rates were around the national average of $13 \%$. This interesting consequence of posttribunal claims may reflect a disillusion with paid-employment for unsuccessful claimants and the use of compensation as start-up capital for applicants receiving awards or settlements (Drinkwater and Latreille, 2008). Unsurprisingly given the dominance of full-time paid employees, employment rates as a whole are highest for those who had withdrawn their cases (81\%) and 8 percentage points lower than the average for those whose cases were dismissed. Around three-quarters of claimants from the remaining outcome groups had jobs at the time of the interview. Whereas the above data relate to the individual's status at the time of the survey, as can be seen, a higher percentage (around 85 per cent) had been employed at some point following the loss of their previous job, ranging from 79 per cent of applicants who lost their case at a hearing, to 87 per cent of those who had been successful.

[Insert Table 1 about here]

The majority of currently out of work claimants whose cases had been dismissed were unemployed, with 19\% of individuals (two thirds of those not 
employed) in this group describing themselves as unemployed ${ }^{14}$. Much lower unemployment rates are observed for other categories. The second highest unemployment rate belonged to claimants who had lost their cases at a hearing, whilst for two of the other categories (those successful at hearings and who settled privately) a higher percentage of individuals were economically inactive rather than seeking work. Further investigation reveals that the most important reason given for inactivity was sickness, followed by retirement. Thus for a small group of individuals, the experience is clearly one which has serious and long-term repercussions which may extend beyond employment to other areas such as health. If on the other hand the health problems etc. pre-date the application, then the fact that these individuals leave the labour market reinforces the view that the compensation in cases upheld at a hearing does not reflect the injustice these individuals have suffered.

Of those who had found subsequent work (i.e. completed spells only), the mean time taken to obtain a new job in our sample was just over 16 weeks. Those who had withdrawn claims for themselves were quickest to find new employment, closely followed by applicants who had had cases decided in their favour. Again, applicants whose cases were dismissed spent the longest time looking for a new job. For those whose job search had not yet resulted in finding another job (i.e. uncompleted spells), the mean reported unemployment duration was 74 weeks, comfortably exceeding the threshold for classification as long-term unemployed. Although the number of

\footnotetext{
${ }^{14}$ Note however, that this category contains only 55 survey respondents in total.
} 
unemployed in each outcome group is small, analysis of the unemployment duration data reveal that unsuccessful claimants at hearings and those who had their claims dismissed had been unemployed longest. Again therefore, for a proportion of appellants, the costs of bringing a claim persist beyond the immediate financial and stress-related costs to more long-term considerations in terms of unemployment and its associated problems.

The final issue to be addressed in this section is to assess the relative quality of the current job match: whether the job was permanent or a stop-gap; the status of the current job relative to the old; and the pay of the current job and the old. Approximately $60 \%$ of the successful job-seekers who provided information reported that their current job was part of a long term career plan rather than a stop-gap. The nature of the current job again varied by case outcome, with claimants whose case was dismissed again faring worst and being most likely to have a stop-gap job. Perhaps somewhat surprisingly, applicants who had been unsuccessful at a hearing were most likely to have a job they described as being part of their long-run career plan.

In respect of pay, around $45 \%$ of claimants reported that their levels of pay were lower in their current job than that from which they had been displaced, and variation was also seen in relative pay by tribunal application outcome. The only group which had a larger proportion of workers who considered their pay to have risen in their current job rather than fallen were those claimants whose case had been privately settled. Successful claimants at hearings were next most likely to report that pay in their new job was higher compared to 
their old job, whilst claimants who had lost at their hearings were the least likely. There was less variation in responses to the relative status of the current job by application outcome, the modal response for each of the groups being 'about the same'. An increase in relative status was however most prevalent for those who had their cases settled by ACAS and (perhaps more surprisingly) claimants who had their cases dismissed, while victors at hearings were most likely to report a decline in relative job status.

The key question to be addressed in the econometric work that follows concerns the extent to which the post-application experience varies according to the characteristics of the appellant and/or the case itself. In particular, we seek to determine whether certain groups are particularly disadvantaged after bringing a grievance (e.g. females, ethnic minorities), and whether the outcome of the case has any bearing on post-application experience (i.e. the extent of labelling by potential employers) after controlling for other case, personal and job-related characteristics. This is clearly important in terms of justice - if the dismissal is 'fair' (as determined by the tribunal), one might attach a different interpretation to the results than if the dismissal is 'unfair'. Similarly, 'settlement' may send a different signal to employers than withdrawing the case or having it dismissed. We go onto examine these issues using a range of econometric models in the next section.

\section{ECONOMETRIC ANALYSIS}

The econometric models that we estimate examine the above measures using a common set of explanatory variables split into three main types: personal 
characteristics (gender, age, marital status, ethnicity and education); the characteristics of the job that the claim related to (part-time, union membership, occupation, industry, tenure, region and workplace size) and case characteristics (its duration, outcome and whether it the displacement was for reasons of redundancy or dismissal (according to the applicant)). The mean for each of these characteristics is reported in Table 2. Given that the information presented in Table 1 indicates that the dependent variables are a mixture of binary, continuous (and censored) duration, and ordered responses, the appropriate type of model to be estimated will vary accordingly. In particular, the binary responses will be modelled using a simple probit, the duration analysis using Cox proportional hazard estimation and the ordered responses by ordered probit. Because of the small numbers of unemployed, we do not report estimates for unemployment duration. Neither do we report the estimates for whether or not the job the claimant currently has is part of their long term career plans because the explanatory variables tended not to be significantly different from zero, even at the $10 \%$ level ${ }^{15}$. Finally, Table A1 contains selected estimates for males and female claimants separately, so that the main gender differences in terms of the impact of personal, job and case characteristics on post-tribunal outcomes can be identified. Such differences will be noted at appropriate points during the commentary on each of the regressions.

\footnotetext{
${ }^{15}$ Interestingly, among the few variables that were significant were having a work-limiting disability and long tenure (both negatively signed).
} 
Table 2 reports marginal effects for each explanatory variable for the probability that the tribunal claimant had a job at the time of their interview and whether they had been employed at any time since leaving the job giving rise to the claim. The probability of currently having a job, or indeed having obtained any job since leaving the employer against whom the claim was brought are both strongly decreasing with age: those aged 55 and over have a current employment rate at least 15 percentage points lower than for other age categories, and workers in this age group are at least 8 percentage points less likely to have secured any work since the separation giving rise to the claim $^{16}$. Females and ethnic minorities were also less likely to have a job at the time of the survey, although these differences were only significant at the $10 \%$ level. Having a limiting, long-term health problem or disability is strongly and negatively related to having a job both at the time of the survey or subsequent to the separation in question, reducing both probabilities by around a third compared with those with no such problems (the marginal effect for non-limiting health problems is similarly signed but smaller in magnitude and marginally significant only for the any job measure).

[Insert Table 2 about here]

In addition to the lower employment probabilities for females, claimants who had previously been part-time had an 8 percentage point lower current employment rate (and a 10 point lower probability of having been employed at

\footnotetext{
${ }^{16} 18 \%$ from the oldest age category went on to retire, but individuals from this category were also more likely to be unemployed and not looking for work and also employed part-time.
} 
all since the separation giving rise to the claim) compared to full-timers, this difference being significant at the $10 \%$ level. However, few of the regional and industry dummies are significant (an exception with regards the latter being construction), while only one occupational dummy is significant (administrative/clerical occupations), and then only for having held any postseparation job. Similarly, workplace size ${ }^{17}$ appears to matter only for having held any job subsequent to leaving the respondent firm, with workers previously employed in the largest workplaces being less likely to have found any subsequent work. The dummy for separation as a result of redundancy has only a negligible effect on the probability of employment, while length of case is not significant at anything approaching conventional levels, although those who had previously submitted a case were significantly more likely to be in employment compared to first time applicants.

Finally, as can be seen, after controlling for other characteristics, those whose cases were dismissed without a hearing (the reference group) were found to have a significantly lower probability of current employment compared with all other outcome groups except for those who had lost their claim at a full merits hearing. This effect varies in magnitude from around 10 percentage points for those reaching private settlements to 15 percentage points for those who withdrew their application. In this regard, if not in pay and status, it is 'losing' that matters rather than 'taking part'. However, case outcome does not appear to impact on whether the applicant had held a job at any time since the

\footnotetext{
17 Ideally one would have data on firm size. Unfortunately this is only asked of the (unmatched) employer sample in SETA 2003.
} 
separation in relation to the ET claim since none of the other dummies is significantly different compared to having a case dismissed. This might suggest that there exist variations in the quality of subsequent matches, with those whose cases were dismissed perhaps forced into temporary or casual jobs.

There are some interesting gender differences worth noting from Table A1. These include that married males are significantly more likely to have a job, whilst the opposite is true for females, although this effect only reaches the margins of significance at the $10 \%$ level. Females who worked part-time are around $17 \%$ less likely to have a job than claimants who were employed on a full-time basis. Taken in combination, these findings may indicate that some marginal female employees choose to leave the labour force or not to search so intensively for new jobs following dismissal or redundancy. The impact of the outcome of the case on the probability of getting a job is similar for males and females, with claimants who had their cases dismissed being less likely to be in employment compared to all other outcomes for both sexes. However, the magnitude of the case outcome effects is much larger for females, with those who won or withdrew their cases being significantly more likely to have a job at the $1 \%$ level.

In Table 3, we present Cox proportional hazard estimates for the time the applicant takes to get a new job after leaving their previous employer. The estimated Kaplan-Meier survival function for both completed and uncompleted spells is shown in Figure 2. The Cox model is often estimated when 
confronted by duration data since it specifies the baseline hazard very flexibly because it is a non-parametric model. Given that some of the applicants find a new job within a week of leaving their previous job, we follow Gu and Kuhn (1998) and Borland et al. (2002) by setting the time taken by this group to get a new job equal to 1 week and increasing all other durations by $1 .^{18}$ The table reports coefficient estimates reflecting the hazard of finding a new job, which implies a negative value attached to a particular explanatory variable indicates a reduced likelihood of leaving the current state and hence a longer duration to finding a new job.

[Insert Table 3 and Figure 2 about here]

The first set of estimates in the table include only completed spells, and interestingly, subject to finding a job, older applicants gained employment more slowly than all bar the youngest age category, albeit none of these effects being significantly different from zero. Several of the personal characteristics do however exert a significant influence on the time taken to find a new job. For example, claimants from the ethnic communities took significantly longer to find a new job following leaving their previous employer, holding other factors constant. Married applicants found new employment significantly faster than those who were single, while having dependent children increases the duration taken to find a new job. Strikingly, a limiting health condition reduces the chances of finding a new job at any given time by

\footnotetext{
${ }^{18}$ The Cox model only uses information on the ranking of durations and so is unaffected by the addition of a scalar.
} 
over $50 \%$ compared to those with no health problem, although it is unclear whether this reflects demand- or supply-side factors. The impact of occupation is also noteworthy, with claimants who previously had a managerial occupation generally taking longer to find a new job. That managers take longer to find alternative work may reflect the greater difficulties such workers face in searching for an appropriate alternative position since these may be in scarcer supply than jobs lower down the occupational hierarchy.

Further variation is also evident by region, with applicants from the default region (Yorkshire and Humberside) taking significantly longer to find a job than applicants from the East Midlands and West Midlands. Moreover, finding a new job appears to be most difficult in the North of England since the only regions where it took longer to find a new job than in Yorkshire and Humberside were the North East and North West.

Perhaps unsurprisingly, the length of the case has a powerful impact on the length of time taken to find a new job, with longer cases increasing a claimant's job search. Again, there are significant differences in terms of case outcome: compared with the reference category of dismissed cases, applicants with other outcomes took statistically significant less time on average to find a new job.

The final pair of columns in Table 3 show the corresponding results when including applicants with uncompleted spells. Results are generally similar to 
those reported above, although the magnitude of the age effects tends to increase. Other estimates are largely unaffected, although the family variables lose significance ${ }^{19}$, with marital status only significant at the $10 \%$ level and dependant children becoming insignificant. The impact of some of the occupational dummies also weakens compared to the previous specification, although manufacturing workers, those with longer job tenures and who worked in large organisations find jobs significantly more slowly. It is also worth noting that the effects of ethnicity and ill-health slightly increase in magnitude, reflecting the adverse impact that these variables have on the probability of finding employment. Similarly, the influence of the outcome dummies tends to increase, with those having their cases dismissed taking significantly longer to find a new job at the $1 \%$ level or better compared to all of the other outcome categories.

Again the impact of the outcome of the case on the time to get a new job is qualitatively the same for males and females, with claimants who had their cases dismissed taking longest to get a new job. However, none of the outcome dummies is significant for males, whereas three of the dummies are significant at the $5 \%$ level or better for females. There are also gender differences in terms of age since older female claimants appear to take the longest to find new job, with only small differences observed for males. Females with dependant children also appear to find employment more quickly than those without.

\footnotetext{
${ }^{19}$ As do the significant regional differences noted previously.
} 
Ordered probit estimates of the respondent's view of their relative pay/status in the current and previous jobs are presented in Table 4. This reveals that younger workers were most likely to report an increase in their relative pay, although none of these differences is statistically significant. However, the impact of age on perceived changes in status is larger, with prime age workers considering status of their current job to be significantly higher compared to the reference group of those aged 55 and over. Females are also significantly more likely to report that their status was lower in their current jobs. Although non-whites reported an increase in relative pay/status in comparison to whites, these differences are not significant. In contrast, those who have a limiting health problem or disability again fare badly: both pay and status are reported to be lower in their current job than the one they left. Claimants who previously had part-time jobs however, were more likely to report that their current jobs had both higher levels of pay and status. This is the case for both males and females, although not significant for females in terms of relative status.

[Insert table 4 about here]

Among the remaining job characteristics, of particular note is the fact that workers previously employed in managerial and professional positions are less likely than the other occupational groups to state that their current job represented a rise in either pay or status compared to their previous job. This effect is particularly pronounced for status, with workers from each of the other occupational groupings except for Professionals associated with a 
significant, positive coefficient. This may reflect the existence of a steeper occupational ladder for managers. If ascent is the result of internal promotion, as one would suspect it often is, then managers lose their position on the ladder when they are 'discharged', i.e. the point of entry for new managerial recruits is often at a lower position, so they are likely to have to start further down the hierarchy.

As might be expected, those with longer tenure are similarly more likely to find that pay and status are reduced relative to their previous position, reflecting the impact of acquired seniority. Both pay and status are also lower for those previously employed in the South East, with the effect being especially pronounced in respect of pay. Workers who had been made redundant are significantly more likely to report an increase in their pay compared to those who were dismissed, which echoes the findings of Arulampalam (2001) and confirms the importance of individual compared with collective 'scarring'. Set in an efficiency wage context, this is also consistent with the notion that dismissal causes the employee to lose the 'avoiding shirking worker premium'. In contrast, none of the case characteristics are significant in the pooled estimates reported in Table 4: it appears that these influence the probability and speed of finding a replacement job, but not the quality of the eventual match. Males who had their cases dismissed actually reported the highest relative levels of pay and status in their new jobs although this was only significant compared to claimants who had lost their cases in the ordered probit for pay. 


\section{CONCLUSIONS}

This paper analyses the impact of job separation on subsequent labour market outcomes using data on employment tribunals in the UK. We argue that by examining such data, we may be able to identify an additional type of stigma associated with the loss of a job in this context - that which is related to the process of making an application, and possibly taking part in, a tribunal. Nevertheless, our findings are generally consistent with the existing literature on worker displacement in that the employment consequences of job loss tend to be worst for older people, females, ethnic minorities and especially those with long-term limiting health problems/disabilities. Other interesting findings relate to occupation, where managerial ( $\&$ professional) workers took longer to find new jobs and the jobs that they currently had were less likely to involve increased pay/status. However, we are not able to examine the longterm impact of job loss within this particular institutional setting, which would be an interesting avenue for future research.

In terms of case outcomes, the probability of currently being employed is lowest for those whose cases had been dismissed without a full merits hearing. Such individuals also took by far the longest of all applicants to find a new job. However, no significant differences were found in relation to the pay and status of the current job compared to the one which was lost. Also, applicants who had made a previous claim actually had higher rates of reemployment than first-time claimants, suggesting that any stigma attached to making an application to an employment tribunal is not increased with further claims. 


\section{REFERENCES}

Autor, D.H., Donohue, John J. III and Stewart, S.J. (2006). The costs of wrongful-discharge laws. Review of Economics and Statistics, 88(2), 211-231.

Arulampalam, W. (2001). Is unemployment really scarring? Effects of unemployment experiences on wage. Economic Journal, 111(475), F585F606.

Arulampalam, W. Gregg, P. and Gregory, M. (2001). Introduction: unemployment scarring. Economic Journal, 111(475), F577-F548.

Banerji, N., Smart, D. and Stevens, M. (1990). Unfair dismissal cases in 198586 - impact on the parties. Employment Gazette, November, 547-552.

Bemmels, B. (1988). Gender effects in discharge arbitration. Industrial and Labor Relations Review, 42(1), 63-76.

Borland, J., Gregg, P., Knight, J. and Wadsworth, J. (2002). They get knocked down. Do they get up again? In P. Kuhn (Ed.), Losing Work, Moving On: Worker Displacement in an International Context (pp. 301-374). Michigan: WE Upjohn Institute for Employment Research.

Brown, S. Frick, B., and Sessions, J. (1997). Unemployment, vacancies and unjust dismissals: the cyclical demand for individual grievance procedures in Germany and Great Britain. Labour: Review of Labour Economics and Industrial Relations, 11(2), 329-349.

Burgess, S., Propper, C. and Wilson, D. (2001). Explaining the growth in the number of applications to Industrial Tribunals, 1972-1997. Department of Trade and Industry Employment Relations Research Series, No. 10.

Casey, B. (1995). Redundancy in Britain: findings from the Labour Force Survey, Department for Education and Employment Research Report, No. 62.

Dennison, P. and Corby, S. (2005). Images in the adversarial mirror: a study of the Employment Tribunal System in Britain, International Employment Relations Review, 11(1/2), 21-36.

Department of Trade and Industry (2002). Findings from the 1998 Survey of Employment Tribunal Applications (Surveys of Applicants and Employers). Department of Trade and Industry Employment Relations Research Series, No. 13.

Dickens, L., Hart, M., Jones, M. and Weekes, B. (1984). The British experience under a statute prohibiting unfair dismissal. Industrial and Labor Relations Review, 37(4), 497-514.

Drinkwater, S. and Latreille, P. (2008). Start-up or fed up? Employment Tribunal claims and entrepreneurship in the UK . Mimeo, University of Surrey. 
Ewing, B.T., North, C.M. and Taylor, B.A. (2005) The employment effects of a "good cause" discharge standard in Montana. Industrial and Labor Relations Review, 59(1), 17-33.

Fallick, B. C. (1993) The industrial mobility of displaced workers. Journal of Labor Economics, 11(2), 302-323.

Fallick, B. C. (1996). A review of the recent empirical literature on displaced workers. Industrial and Labor Relations Review, 50(1), 5-16.

Farber, H. (1997). The changing face of job loss in the United States, 19811995. Brookings Papers on Economic Activity: Microeconomics, 55-142.

Fox, M. and G. Dix (2002). Employment Tribunal outcomes, Acas Working Paper, No. 01.

Gregg. P. (2001). The impact of youth unemployment on adult unemployment in the NCDS. Economic Journal, 111(475), F626-653.

Gregory, M. and Jukes, R. (1997). Unemployment and subsequent earnings: estimating scarring among British men 1984-94. Economic Journal, 111(475), pp. F607-625.

Gu, W. and Kuhn, P. (1998). A theory of holdouts in wage bargaining. American Economic Review, 88(3), 428-449.

Gustafson, C. (1998). Job displacement and mobility of younger workers'. Center for Labor Economics, University of California Berkeley Working Paper No. 8.

Harrison, T. (1990). Employment Law, Sunderland: Business Education Publishers.

Hayward, B., Peters, M., Rousseau, N. and Seeds, K. (2004a). Findings from the Survey of Employment Tribunal Applications 2003. Department of Trade and Industry Employment Relations Research Series, No. 33.

Hayward, B., Peters, M., Rousseau, N. and Seeds, K. (2004b). Technical report: fourth periodic Survey of Employment Tribunal Applications (SETA) 2003. Mimeo, Department of Trade and Industry.

Huff Stevens, A. (1997). Persistent effects of job displacement: The importance of multiple job losses. Journal of Labor Economics, 15(1), 165188.

Jacobsen, L., LaLonde, R. and Sullivan, D. (1993). Earnings losses of displaced workers. American Economic Review, 83(4), 685-709. 
Kletzer, L. (1998). Job displacement. Journal of Economic Perspectives, 12(1), 115-136.

Knight, K.G. and Latreille, P.L. (2000). How far do cases go? Resolution in Industrial Tribunal applications. The Manchester School, 68(6), 723-744.

Knight, K.G. and Latreille, P.L. (2001). Gender effects in British unfair dismissal tribunal hearings. Industrial and Labor Relations Review, 54(4), 816-834

Latreille, P.L. (2007a). Further reflections on images in the adversarial mirror: some historical matched sample evidence. Swansea University Economics Working Paper No. SBE-E/2007/10.

Latreille, P.L. (2007b). The settlement of Employment Tribunal cases: evidence from SETA 2003. Department for Business, Enterprise and Regulatory Reform Employment Relations Research Series, No. 61.

Latreille, P.L., Latreille, J.A. and Knight, K.G. (2004). Findings from the 1998 Survey of Representatives in Employment Tribunal cases. Department of Trade \& Industry Employment Relations Research Series, No. 35.

Latreille, P.L., Latreille, J.A. and Knight, K.G. (2005). Making a difference? Legal representation in Employment Tribunal cases: evidence from a Survey of Representatives. Industrial Law Journal, 34(4), 308-330.

Latreille, P.L., Latreille, J.A. and Knight, K.G. (2007). Employment Tribunals and Acas: evidence from a Survey of Representatives. Industrial Relations Journal, 38(2), 138-156.

McCall, B. (1997). The determinants of full-time versus part-time reemployment following job displacement. Journal of Labor Economics, 15(4), 714-734.

Ruhm, C. J. (1991). Are workers permanently scarred by job displacements? American Economic Review, 81(1), 319-324.

Saridakis, G., Sen-Gupta, S., Edwards, P. and Storey, D. (2008). The impact of enterprise size on Employment Tribunal incidence and outcomes: evidence from Britain. British Journal of Industrial Relations, forthcoming.

Stevens, M. (1988). Unfair dismissal cases in 1985-86 - characteristics of parties. Employment Gazette, December, 651-659.

Tremlett, N. and N. Banerji (1994). The 1992 Survey of Industrial Tribunal Applications. Employment Department Research Series, No. 22. 
Urwin, P., Murphy, R., and Michielsens, E. (2007). Employee voice regimes and the characteristics of conflict: an analysis of the 2003 Survey of Employment Tribunal Applications. Human Resource Management Journal, 17(2), 178-197.

Weir, G. (2003). Self-employment in the UK labour market. Labour Market Trends, September, 441-451. 
TABLE 1: POST-APPLICATION LABOUR MARKET STATUS BY OUTCOME OF EMPLOYMENT TRIBUNAL APPLICATION

\begin{tabular}{|c|c|c|c|c|c|c|}
\hline & $\begin{array}{c}\text { Employer } \\
\text { won }\end{array}$ & $\begin{array}{l}\text { Applicant } \\
\text { won }\end{array}$ & $\begin{array}{c}\text { Acas conciliated } \\
\text { settlement }\end{array}$ & $\begin{array}{c}\text { Private } \\
\text { settlement }\end{array}$ & Withdrawn & $\begin{array}{c}\text { Dismissed/ } \\
\text { disposed of by ETS }\end{array}$ \\
\hline \multicolumn{7}{|l|}{ Current economic activity (\%) } \\
\hline Full-time employee & 49.6 & 57.3 & 57.1 & 49.6 & 61.4 & 44.0 \\
\hline Part-time employee & 9.0 & 10.1 & 11.0 & 11.9 & 9.3 & 15.1 \\
\hline Self-employed & 14.5 & 10.6 & 9.8 & 13.6 & 10.6 & 10.2 \\
\hline Unemployed & 14.2 & 8.3 & 11.8 & 10.5 & 9.7 & 18.5 \\
\hline Inactive & 12.7 & 13.7 & 10.3 & 14.4 & 9.1 & 12.2 \\
\hline In employment & 73.1 & 78.0 & 78.0 & 75.1 & 81.3 & 69.2 \\
\hline \multicolumn{7}{|c|}{ Any job since leaving job giving rise to claim (\%) } \\
\hline Yes & 79.4 & 87.2 & 85.7 & 82.0 & 86.6 & 82.9 \\
\hline No & 20.6 & 12.8 & 14.3 & 18.0 & 13.4 & 17.1 \\
\hline \multicolumn{7}{|l|}{ Time to get a new job (weeks) } \\
\hline Average & 17.0 & 14.2 & 14.9 & 20.8 & 14.3 & 30.1 \\
\hline Standard deviation & 17.9 & 17.1 & 20.3 & 28.6 & 18.6 & 49.2 \\
\hline \multicolumn{7}{|c|}{ Duration of current unemployment spell (weeks) } \\
\hline Average & 78.2 & 51.0 & 59.8 & 56.2 & 59.1 & 74.2 \\
\hline Standard deviation & 21.2 & 33.1 & 34.5 & 34.9 & 47.4 & 50.6 \\
\hline \multicolumn{7}{|l|}{ Relative pay in new job (\%) } \\
\hline More & 25.7 & 44.5 & 37.9 & 46.8 & 38.3 & 35.5 \\
\hline About the same & 16.1 & 12.6 & 17.6 & 12.2 & 17.1 & 12.9 \\
\hline Less & 58.2 & 42.9 & 44.6 & 41.0 & 44.6 & 51.6 \\
\hline \multicolumn{7}{|l|}{ Relative status of new job (\%) } \\
\hline Higher & 27.6 & 21.4 & 33.5 & 28.2 & 28.4 & 30.6 \\
\hline About the same & 43.1 & 44.7 & 37.3 & 39.0 & 36.4 & 35.7 \\
\hline Lower & 29.3 & 33.9 & 29.2 & 32.8 & 35.3 & 33.7 \\
\hline \multicolumn{7}{|l|}{ Nature of new job (\%) } \\
\hline Stop gap & 28.7 & 30.2 & 33.0 & 37.1 & 34.7 & 46.5 \\
\hline Part of long term career plan & 71.3 & 69.8 & 67.0 & 63.0 & 65.3 & 53.5 \\
\hline Unweighted base & 100 & 209 & 661 & 151 & 173 & 55 \\
\hline
\end{tabular}

Unweighted base

Notes: Data are weighted and relate to job separations for dismissal and redundancy only. The time to get a new job statistics include those individuals not in employment at the time of the interview but who had found a job following making a tribunal claim. 
TABLE 2: PROBIT ESTIMATES OF PROBABILITY OF HAVING A JOB

\begin{tabular}{|c|c|c|c|c|c|}
\hline & \multirow[b]{2}{*}{ Mean } & \multicolumn{2}{|c|}{ "Currently employed } & \multicolumn{2}{|c|}{ "Any job post-separation } \\
\hline & & $\begin{array}{c}\text { Marginal } \\
\text { effect }\end{array}$ & $\begin{array}{c}\text { Standard } \\
\text { error }\end{array}$ & $\begin{array}{c}\text { Marginal } \\
\text { effect }\end{array}$ & $\begin{array}{c}\text { Standard } \\
\text { error }\end{array}$ \\
\hline \multicolumn{6}{|l|}{ Personal characteristics } \\
\hline Aged 16-24 & 0.113 & $0.160^{* * *}$ & 0.029 & $0.132^{\star * \star}$ & 0.014 \\
\hline Aged 25-34 & 0.173 & $0.189 * * \star$ & 0.026 & $0.118 * \star \star$ & 0.017 \\
\hline Aged 35-44 & 0.271 & $0.179 * \star \star$ & 0.030 & $0.111^{\star \star \star}$ & 0.020 \\
\hline Aged 45-54 & 0.257 & $0.167^{\star \star *}$ & 0.028 & $0.083^{\star * *}$ & 0.020 \\
\hline Married & 0.683 & 0.023 & 0.032 & 0.013 & 0.025 \\
\hline Dependent children $<16$ & 0.359 & -0.035 & 0.032 & -0.020 & 0.023 \\
\hline Non-white & 0.095 & $-0.095^{\star}$ & 0.056 & -0.047 & 0.040 \\
\hline Non-limiting health problem & 0.066 & -0.097 & 0.060 & $-0.095^{\star}$ & 0.050 \\
\hline Limiting health problem & 0.107 & $-0.330 * \star \star$ & 0.053 & $-0.293^{\star \star \star}$ & 0.050 \\
\hline Degree & 0.168 & 0.019 & 0.045 & -0.006 & 0.034 \\
\hline Other higher education & 0.143 & 0.007 & 0.044 & 0.014 & 0.031 \\
\hline A levels or equivalent & 0.206 & 0.057 & 0.037 & 0.031 & 0.027 \\
\hline \multicolumn{6}{|l|}{ Previous job characteristics } \\
\hline Part-time & 0.138 & $-0.078 *$ & 0.045 & $-0.101^{* *}$ & 0.041 \\
\hline Tenure $2-5$ years & 0.315 & 0.043 & 0.032 & 0.039 & 0.024 \\
\hline Tenure $>5$ years & 0.348 & -0.005 & 0.033 & -0.039 & 0.027 \\
\hline Professional & 0.044 & 0.021 & 0.067 & 0.043 & 0.039 \\
\hline Associate professional & 0.096 & 0.068 & 0.044 & 0.024 & 0.033 \\
\hline Administrative \& secretarial & 0.102 & 0.022 & 0.046 & $0.055^{\star \star}$ & 0.024 \\
\hline Skilled trades & 0.116 & -0.016 & 0.050 & -0.019 & 0.038 \\
\hline Personal services & 0.036 & -0.076 & 0.086 & -0.056 & 0.070 \\
\hline Sales \& customer services & 0.087 & 0.003 & 0.054 & 0.012 & 0.037 \\
\hline Process, plant \& machinery & 0.116 & 0.014 & 0.047 & 0.021 & 0.032 \\
\hline Elementary & 0.127 & -0.005 & 0.048 & -0.009 & 0.037 \\
\hline Manufacturing & 0.221 & -0.068 & 0.047 & -0.018 & 0.033 \\
\hline Construction & 0.092 & $0.123^{\star \star \star}$ & 0.038 & 0.043 & 0.033 \\
\hline
\end{tabular}




\begin{tabular}{|c|c|c|c|c|c|}
\hline Wholesale / retail & 0.161 & 0.033 & 0.046 & 0.017 & 0.035 \\
\hline Hotels \& restaurants & 0.054 & 0.026 & 0.060 & -0.028 & 0.053 \\
\hline Finance & 0.075 & 0.048 & 0.054 & -0.013 & 0.045 \\
\hline Services \& public admin. & 0.250 & 0.037 & 0.042 & 0.026 & 0.029 \\
\hline East Midlands & 0.078 & -0.031 & 0.073 & -0.113 & 0.082 \\
\hline East & 0.066 & 0.005 & 0.073 & -0.022 & 0.063 \\
\hline London & 0.120 & -0.082 & 0.074 & -0.165 & 0.085 \\
\hline North East & 0.060 & -0.054 & 0.077 & -0.076 & 0.078 \\
\hline North West & 0.145 & 0.027 & 0.055 & -0.062 & 0.062 \\
\hline Scotland & 0.085 & -0.035 & 0.056 & -0.085 & 0.057 \\
\hline South East & 0.123 & -0.013 & 0.065 & -0.041 & 0.064 \\
\hline South West & 0.079 & 0.001 & 0.065 & -0.021 & 0.060 \\
\hline Wales & 0.054 & -0.063 & 0.089 & 0.034 & 0.056 \\
\hline West Midlands & 0.096 & -0.090 & 0.076 & -0.179 & 0.089 \\
\hline Workplace size: 25-249 & 0.385 & 0.015 & 0.030 & -0.027 & 0.024 \\
\hline Workplace size: 250+ & 0.146 & -0.048 & 0.044 & $-0.072^{\star}$ & 0.038 \\
\hline Union member & 0.203 & 0.018 & 0.034 & 0.034 & 0.022 \\
\hline Case characteristics & & & & & \\
\hline Length of case (/1000) & 137.299 & 0.011 & 0.140 & 0.077 & 0.100 \\
\hline Previous case & 0.059 & $0.090^{\star \star}$ & 0.043 & 0.047 & 0.031 \\
\hline Employer won & 0.068 & 0.081 & 0.060 & 0.022 & 0.049 \\
\hline Applicant won & 0.146 & $0.111^{\star \star}$ & 0.051 & 0.037 & 0.042 \\
\hline Acas-conciliated settlement & 0.497 & $0.130^{\star \star}$ & 0.062 & 0.032 & 0.045 \\
\hline Private settlement & 0.115 & $0.096^{*}$ & 0.052 & 0.021 & 0.047 \\
\hline Withdrawn & 0.131 & $0.148^{\star \star \star}$ & 0.041 & 0.056 & 0.036 \\
\hline Redundancy & 0.469 & -0.013 & 0.029 & 0.003 & 0.021 \\
\hline Number of observations & 1052 & \multicolumn{2}{|c|}{1052} & \multicolumn{2}{|c|}{1052} \\
\hline
\end{tabular}

Notes: Reference categories are aged 55 \& over; no qualifications; no health problem; managerial occupation; tenure 1-2 years; agriculture/mining/transport/communications/utilities; workplace size 1-25; Yorkshire \& Humberside; case dismissed. Marginal effects are calculated at sample means. ${ }^{*}$ denotes significance at the $10 \%$ level, ${ }^{* \star}$ at the $5 \%$ level and ${ }^{\star \star \star}$ at the $1 \%$ level using two tailed tests. Mean length of case reported in days. 
TABLE 3: COX PROPORTIONAL HAZARD ESTIMATES OF TIME TO GET A NEW JOB

\begin{tabular}{|c|c|c|c|c|}
\hline & \multicolumn{2}{|c|}{ Completed spells only } & \multicolumn{2}{|c|}{ Completed and uncompleted spells } \\
\hline & Coefficient & Standard error & Coefficient & Standard error \\
\hline \multicolumn{5}{|l|}{ Personal characteristics } \\
\hline Female & -0.026 & 0.085 & -0.076 & 0.080 \\
\hline Aged 16-24 & -0.014 & 0.132 & 0.074 & 0.134 \\
\hline Aged 25-34 & 0.096 & 0.118 & 0.191 & 0.117 \\
\hline Aged 35-44 & 0.129 & 0.113 & 0.102 & 0.115 \\
\hline Aged 45-54 & 0.036 & 0.111 & 0.083 & 0.106 \\
\hline Married & $0.244^{\star \star \star}$ & 0.081 & $0.131^{*}$ & 0.076 \\
\hline Dependent children $<16$ & $-0.146^{\star}$ & 0.078 & -0.063 & 0.073 \\
\hline Non-white & $-0.284^{\star *}$ & 0.125 & $-0.307^{\star \star}$ & 0.119 \\
\hline Non-limiting health problem & -0.029 & 0.132 & -0.057 & 0.137 \\
\hline Limiting health problem & $-0.536^{\star \star \star}$ & 0.124 & $-0.546^{\star \star \star}$ & 0.109 \\
\hline Degree & -0.053 & 0.128 & -0.001 & 0.120 \\
\hline Other higher education & 0.070 & 0.120 & 0.037 & 0.116 \\
\hline A levels or equivalent & 0.130 & 0.103 & $0.196^{*}$ & 0.102 \\
\hline Other qualification & 0.040 & 0.103 & -0.004 & 0.102 \\
\hline \multicolumn{5}{|l|}{ Previous job characteristics } \\
\hline Part-time & 0.120 & 0.127 & -0.074 & 0.116 \\
\hline Tenure $2-5$ years & -0.004 & 0.080 & 0.019 & 0.077 \\
\hline Tenure $>5$ years & -0.141 & 0.088 & $-0.149 *$ & 0.084 \\
\hline Professional & 0.156 & 0.149 & 0.064 & 0.154 \\
\hline Associate professional & $0.289^{\star *}$ & 0.120 & 0.151 & 0.125 \\
\hline Administrative \& secretarial & 0.092 & 0.122 & 0.173 & 0.114 \\
\hline Skilled trades & $0.227^{\star}$ & 0.119 & 0.115 & 0.124 \\
\hline Personal services & 0.128 & 0.242 & -0.067 & 0.241 \\
\hline Sales \& customer services & 0.161 & 0.133 & 0.176 & 0.124 \\
\hline Process, plant \& machinery & $0.309 * \star$ & 0.121 & $0.290 * \star$ & 0.115 \\
\hline Elementary & 0.115 & 0.123 & 0.039 & 0.114 \\
\hline Manufacturing & -0.140 & 0.116 & $-0.218^{*}$ & 0.111 \\
\hline Construction & 0.236 & 0.144 & 0.233 & 0.142 \\
\hline Wholesale / retail & $-0.208^{*}$ & 0.124 & -0.165 & 0.117 \\
\hline
\end{tabular}




\begin{tabular}{|c|c|c|c|c|}
\hline Hotels \& restaurants & -0.217 & 0.172 & -0.068 & 0.157 \\
\hline Finance & -0.012 & 0.138 & -0.025 & 0.130 \\
\hline Services \& public admin. & $-0.211^{*}$ & 0.118 & -0.138 & 0.112 \\
\hline East Midlands & $0.545^{\star \star \star}$ & 0.162 & 0.276 & 0.169 \\
\hline East & 0.028 & 0.184 & -0.073 & 0.181 \\
\hline London & 0.123 & 0.145 & -0.076 & 0.141 \\
\hline North East & -0.049 & 0.177 & -0.118 & 0.180 \\
\hline North West & -0.068 & 0.152 & -0.093 & 0.145 \\
\hline Scotland & 0.081 & 0.135 & -0.046 & 0.132 \\
\hline South East & 0.023 & 0.132 & -0.081 & 0.140 \\
\hline South West & 0.120 & 0.169 & 0.117 & 0.163 \\
\hline Wales & 0.233 & 0.178 & 0.136 & 0.185 \\
\hline West Midlands & $0.315^{\star}$ & 0.166 & 0.072 & 0.164 \\
\hline Workplace size: 25-249 & -0.067 & 0.074 & -0.021 & 0.070 \\
\hline Workplace size: 250+ & -0.115 & 0.097 & $-0.226 * \star$ & 0.099 \\
\hline Union member & -0.147 & 0.090 & -0.021 & 0.086 \\
\hline \multicolumn{5}{|l|}{ Case characteristics } \\
\hline Length of case (/1000) & $-0.730 * \star$ & 0.325 & $-0.739 * \star$ & 0.317 \\
\hline Previous case & 0.126 & 0.148 & 0.047 & 0.142 \\
\hline Employer won & $0.446^{\star \star}$ & 0.203 & $0.567^{\star \star \star}$ & 0.190 \\
\hline Applicant won & $0.479 * \star$ & 0.191 & $0.603^{\star \star *}$ & 0.179 \\
\hline Acas-conciliated settlement & $0.624^{\star \star \star}$ & 0.177 & $0.590 * \star \star$ & 0.166 \\
\hline Private settlement & $0.506^{\star \star}$ & 0.201 & $0.543^{* * *}$ & 0.190 \\
\hline Withdrawn & $0.581^{\star \star *}$ & 0.192 & $0.655^{\star \star \star}$ & 0.183 \\
\hline Redundancy & -0.030 & 0.070 & -0.057 & 0.066 \\
\hline Number of observations & \multicolumn{2}{|c|}{879} & \multicolumn{2}{|c|}{944} \\
\hline
\end{tabular}

Note: See notes to Table 2. 
TABLE 4: ORDERED PROBIT ESTIMATES OF RELATIVE PAY \& STATUS OF CURRENT JOB COMPARED WITH PREVIOUS JOB

\begin{tabular}{|c|c|c|c|c|}
\hline & \multicolumn{2}{|c|}{ Pay } & \multicolumn{2}{|c|}{ Status } \\
\hline & Coefficient & Standard error & Coefficient & Standard error \\
\hline \multicolumn{5}{|l|}{ Personal characteristics } \\
\hline Female & -0.132 & 0.121 & $-0.261^{\star *}$ & 0.117 \\
\hline Aged 16-24 & 0.246 & 0.193 & 0.237 & 0.184 \\
\hline Aged 25-34 & 0.037 & 0.173 & $0.428 * \star$ & 0.168 \\
\hline Aged 35-44 & 0.240 & 0.162 & $0.399 * \star \star$ & 0.152 \\
\hline Aged $45-54$ & 0.016 & 0.152 & 0.190 & 0.140 \\
\hline Married & 0.019 & 0.113 & -0.102 & 0.107 \\
\hline Dependent children $<16$ & -0.170 & 0.105 & -0.112 & 0.102 \\
\hline Non-white & 0.157 & 0.185 & 0.225 & 0.170 \\
\hline Non-limiting health problem & -0.003 & 0.188 & -0.199 & 0.174 \\
\hline Limiting health problem & $-0.433^{\star \star}$ & 0.184 & $-0.417^{* *}$ & 0.183 \\
\hline Degree & -0.001 & 0.172 & 0.021 & 0.167 \\
\hline Other higher education & -0.115 & 0.153 & -0.021 & 0.155 \\
\hline A levels or equivalent & -0.007 & 0.136 & -0.003 & 0.136 \\
\hline Other qualification & 0.083 & 0.141 & -0.192 & 0.133 \\
\hline \multicolumn{5}{|l|}{ Previous job characteristics } \\
\hline Part-time & $0.596^{\star \star *}$ & 0.155 & $0.284^{\star \star}$ & 0.141 \\
\hline Tenure $2-5$ years & -0.146 & 0.110 & -0.017 & 0.101 \\
\hline Tenure $>5$ years & $-0.647^{\star \star \star *}$ & 0.121 & $-0.437^{\star * *}$ & 0.114 \\
\hline Professional & 0.169 & 0.245 & 0.073 & 0.251 \\
\hline Associate professional & $0.375^{\star *}$ & 0.178 & $0.557^{* * *}$ & 0.160 \\
\hline Administrative \& secretarial & $0.385^{\star \star}$ & 0.189 & $0.543^{\star \star \star}$ & 0.177 \\
\hline Skilled trades & $0.471^{\star \star \star}$ & 0.165 & $0.391^{\star \star \star}$ & 0.151 \\
\hline Personal services & $0.599 * *$ & 0.273 & $0.816^{\star \star \star}$ & 0.263 \\
\hline Sales \& customer services & $0.434^{\star \star}$ & 0.216 & $0.407^{* *}$ & 0.197 \\
\hline Process, plant \& machinery & 0.171 & 0.159 & $0.490 * \star \star$ & 0.161 \\
\hline Elementary & $0.435^{\star \star \star}$ & 0.161 & $0.788^{\star * \star}$ & 0.166 \\
\hline Manufacturing & -0.074 & 0.158 & 0.038 & 0.154 \\
\hline Construction & 0.183 & 0.175 & -0.002 & 0.170 \\
\hline
\end{tabular}




\begin{tabular}{|c|c|c|c|c|}
\hline Wholesale / retail & 0.042 & 0.169 & 0.161 & 0.162 \\
\hline Hotels and restaurants & -0.163 & 0.232 & 0.092 & 0.226 \\
\hline Finance & -0.327 & 0.217 & -0.310 & 0.207 \\
\hline Services \& public admin. & -0.109 & 0.162 & -0.150 & 0.158 \\
\hline Manufacturing & -0.074 & 0.158 & 0.038 & 0.154 \\
\hline Construction & 0.183 & 0.175 & -0.002 & 0.170 \\
\hline Wholesale / retail & 0.042 & 0.169 & 0.161 & 0.162 \\
\hline Hotels \& restaurants & -0.163 & 0.232 & 0.092 & 0.226 \\
\hline Finance & -0.327 & 0.217 & -0.310 & 0.207 \\
\hline Services \& public admin. & -0.109 & 0.162 & -0.150 & 0.158 \\
\hline East Midlands & -0.143 & 0.222 & -0.010 & 0.226 \\
\hline East & -0.279 & 0.247 & -0.067 & 0.241 \\
\hline London & -0.051 & 0.211 & -0.193 & 0.202 \\
\hline North East & -0.264 & 0.216 & -0.075 & 0.220 \\
\hline North West & -0.007 & 0.193 & 0.058 & 0.190 \\
\hline Scotland & -0.143 & 0.175 & -0.092 & 0.177 \\
\hline South East & $-0.527^{\star \star \star}$ & 0.203 & $-0.385^{\star}$ & 0.200 \\
\hline South West & -0.224 & 0.218 & -0.160 & 0.236 \\
\hline Wales & 0.075 & 0.259 & 0.182 & 0.255 \\
\hline West Midlands & 0.020 & 0.225 & -0.029 & 0.219 \\
\hline Workplace size: 25-249 & $-0.222^{\star \star}$ & 0.098 & $-0.173^{*}$ & 0.094 \\
\hline Workplace size: 250+ & $-0.309 * \star$ & 0.149 & $-0.248^{*}$ & 0.146 \\
\hline Union member & -0.026 & 0.120 & -0.139 & 0.115 \\
\hline \multicolumn{5}{|l|}{ Case characteristics } \\
\hline Length of case $(/ 1000)$ & 0.000 & 0.001 & 0.000 & 0.001 \\
\hline Previous case & -0.077 & 0.188 & 0.227 & 0.188 \\
\hline Employer won & -0.384 & 0.309 & -0.185 & 0.304 \\
\hline Applicant won & -0.262 & 0.270 & -0.337 & 0.261 \\
\hline Acas-conciliated settlement & -0.173 & 0.241 & -0.102 & 0.244 \\
\hline Private settlement & 0.056 & 0.277 & -0.200 & 0.274 \\
\hline Withdrawn & -0.109 & 0.261 & -0.247 & 0.265 \\
\hline Redundancy & $0.254^{\star \star \star}$ & 0.098 & -0.020 & 0.091 \\
\hline Number of observations & & 791 & & 773 \\
\hline
\end{tabular}


TABLE A1: SELECTED REGRESSION ESTIMATES BY GENDER

\begin{tabular}{|c|c|c|c|c|c|c|c|c|}
\hline & \multicolumn{4}{|c|}{ Male } & \multicolumn{4}{|c|}{$\begin{array}{rr}\text { Female } \\
\end{array}$} \\
\hline & $\mathrm{P}(\mathrm{Job})$ & Time New Job & Pay & Status & $\mathrm{P}(\mathrm{Job})$ & Time New Job & Pay & Status \\
\hline \multirow{2}{*}{ Aged 16-24 } & $0.170^{\star \star *}$ & -0.187 & 0.097 & 0.346 & 0.007 & 0.214 & 0.356 & -0.068 \\
\hline & $(0.020)$ & $(0.290)$ & $(0.250)$ & $(0.242)$ & $(0.097)$ & $(0.212)$ & $(0.340)$ & $(0.321)$ \\
\hline \multirow{2}{*}{ Aged 25-34 } & $0.175^{\star \star \star}$ & -0.050 & 0.060 & $0.577^{* \star *}$ & $0.124^{*}$ & $0.389 *$ & 0.159 & $0.404^{\prime}$ \\
\hline & $(0.020)$ & $(0.256)$ & $(0.218)$ & $(0.200)$ & $(0.073)$ & $(0.222)$ & $(0.326)$ & $(0.327)$ \\
\hline \multirow{2}{*}{ Aged 35-44 } & $0.183^{\star * *}$ & 0.005 & 0.332 & $0.357^{*}$ & 0.116 & $0.512^{* *}$ & 0.365 & $0.734^{* *}$ \\
\hline & $(0.028)$ & $(0.146)$ & $(0.206)$ & $(0.188)$ & $(0.074)$ & $(0.202)$ & $(0.307)$ & $(0.287)$ \\
\hline \multirow{2}{*}{ Aged $45-54$} & $0.149 * \star *$ & -0.081 & 0.087 & 0.272 & $0.194^{\star \star \star}$ & $0.362^{*}$ & -0.093 & 0.199 \\
\hline & $(0.029)$ & $(0.143)$ & $(0.187)$ & $(0.167)$ & $(0.054)$ & $(0.195)$ & $(0.289)$ & $(0.270)$ \\
\hline \multirow{2}{*}{ Married } & $0.101^{\star \star}$ & 0.170 & -0.087 & -0.193 & -0.086 & $0.218^{*}$ & 0.090 & -0.033 \\
\hline & $(0.043)$ & $(0.104$ & $(0.149)$ & $(0.145)$ & $(0.053)$ & $(0.131)$ & $(0.193)$ & $(0.182)$ \\
\hline \multirow{2}{*}{ Dependent Children } & -0.030 & -0.034 & -0.165 & -0.047 & -0.049 & $-0.344^{* *}$ & -0.311 & -0.396 \\
\hline & $(0.036)$ & $(0.092)$ & $(0.127)$ & $(0.124)$ & $(0.065)$ & $(0.170)$ & $(0.211)$ & $(0.209)$ \\
\hline \multirow{2}{*}{ Non-white } & -0.095 & $-0.263^{*}$ & 0.008 & 0.335 & -0.016 & -0.214 & 0.207 & -0.155 \\
\hline & $(0.066)$ & $(0.159)$ & $(0.235)$ & $(0.224)$ & $(0.092)$ & $(0.207)$ & $(0.382)$ & $(0.296)$ \\
\hline \multirow{2}{*}{ Part-time } & 0.043 & 0.751 & $0.838^{* * *}$ & $0.731^{\star \star \star *}$ & $-0.167^{* * *}$ & -0.069 & $0.703^{\star * *}$ & 0.103 \\
\hline & $(0.055)$ & $(0.225)$ & $(0.292)$ & $(0.271)$ & $(0.062)$ & $(0.165)$ & $(0.208)$ & $(0.196)$ \\
\hline \multirow{2}{*}{ Employer won } & 0.077 & 0.300 & $-0.790^{\star *}$ & -0.496 & 0.107 & $1.113^{* \star *}$ & 0.280 & 0.799 \\
\hline & $(0.057)$ & $(0.246)$ & $(0.362)$ & $(0.350)$ & $(0.117)$ & $(0.404)$ & $(0.701)$ & $(0.628)$ \\
\hline \multirow{2}{*}{ Applicant won } & 0.072 & 0.428 & -0.581 & -0.406 & $0.219 * \star \star *$ & $0.849 * \star$ & -0.103 & -0.351 \\
\hline & $(0.059)$ & $(0.239)$ & $(0.314)$ & $(0.308)$ & $(0.071)$ & $(0.334)$ & $(0.508)$ & $(0.492)$ \\
\hline \multirow{2}{*}{ Acas-conciliated settlement } & $0.129 *$ & 0.675 & -0.404 & -0.195 & 0.172 & $0.711^{\star *}$ & -0.142 & -0.005 \\
\hline & $(0.066)$ & $(0.225)$ & $(0.276)$ & $(0.285)$ & $(0.126)$ & $(0.286)$ & $(0.461)$ & $(0.457)$ \\
\hline \multirow{2}{*}{ Private settlement } & 0.088 & 0.572 & -0.089 & -0.153 & 0.137 & 0.553 & 0.166 & -0.470 \\
\hline & $(0.051)$ & $(0.249)$ & $(0.320)$ & $(0.322$ & $(0.099)$ & $(0.350)$ & $(0.540)$ & $(0.529)$ \\
\hline \multirow{2}{*}{ Withdrawn } & $0.112^{*}$ & 0.637 & -0.225 & -0.091 & $0.252^{\star \star *}$ & 0.558 & -0.434 & -0.833 \\
\hline & $(0.046)$ & $(0.245)$ & $(0.304)$ & $(0.311)$ & $(0.047)$ & $(0.343)$ & $(0.521)$ & $(0.519)$ \\
\hline $\mathrm{N}$ & 694 & 590 & 539 & 528 & 358 & 289 & 252 & 245 \\
\hline
\end{tabular}

Notes: P(Job) reports marginal effects from a probit model for the probability of having a job, Time New Job the survival estimates from a regression for the time to get a new job for completed spells, Pay reports ordered probit estimates for the relative pay in the new job and Status the relative status in the new job. See Tables 2-4 for other explanatory variables included in the model and details of the reference categories. Standard errors in parentheses. * denotes significance at the $10 \%$ level, ${ }^{* *}$ at the $5 \%$ level and ${ }^{* *}$ at the $1 \%$ level using two tailed tests. 
FIGURE 1: EMPLOYMENT TRIBUNAL CLAIMS 1976-2005/6

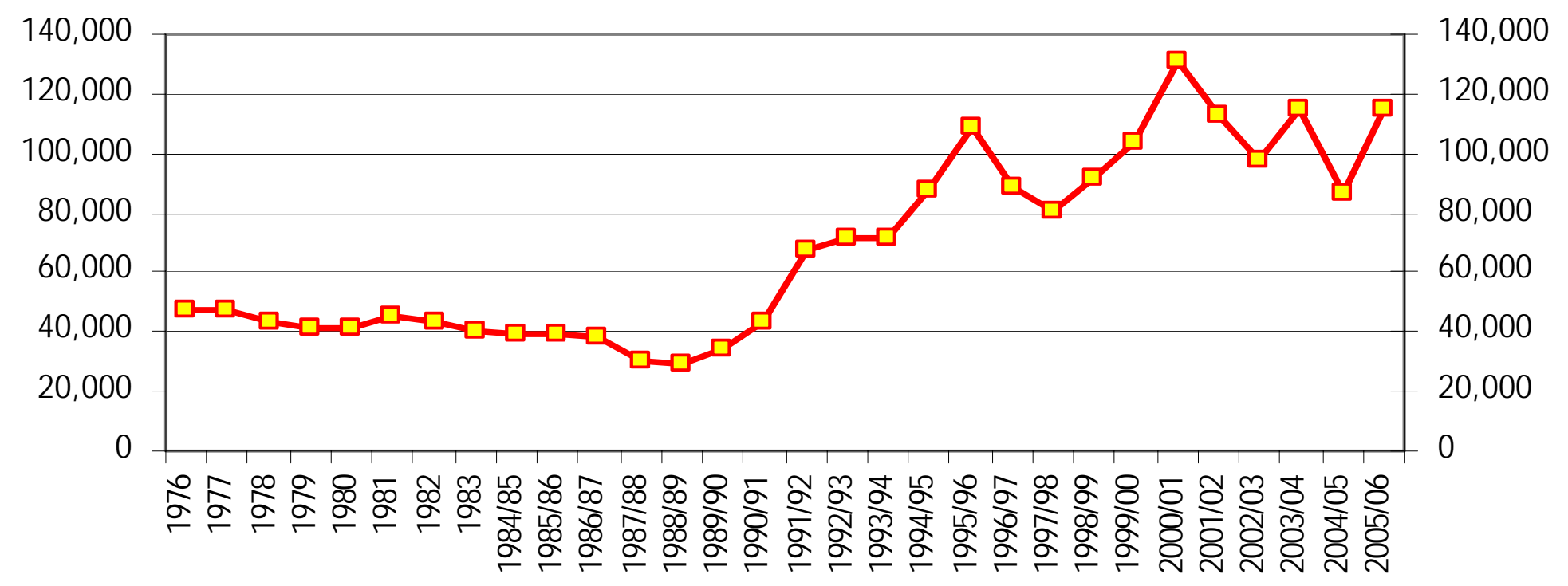

Source: ETS internal statistical information, 1976-1997/8; ETS Annual Reports thereafter. 
FIGURE 2: ESTIMATED KAPLAN-MEIER SURVIVAL FUNCTIONS

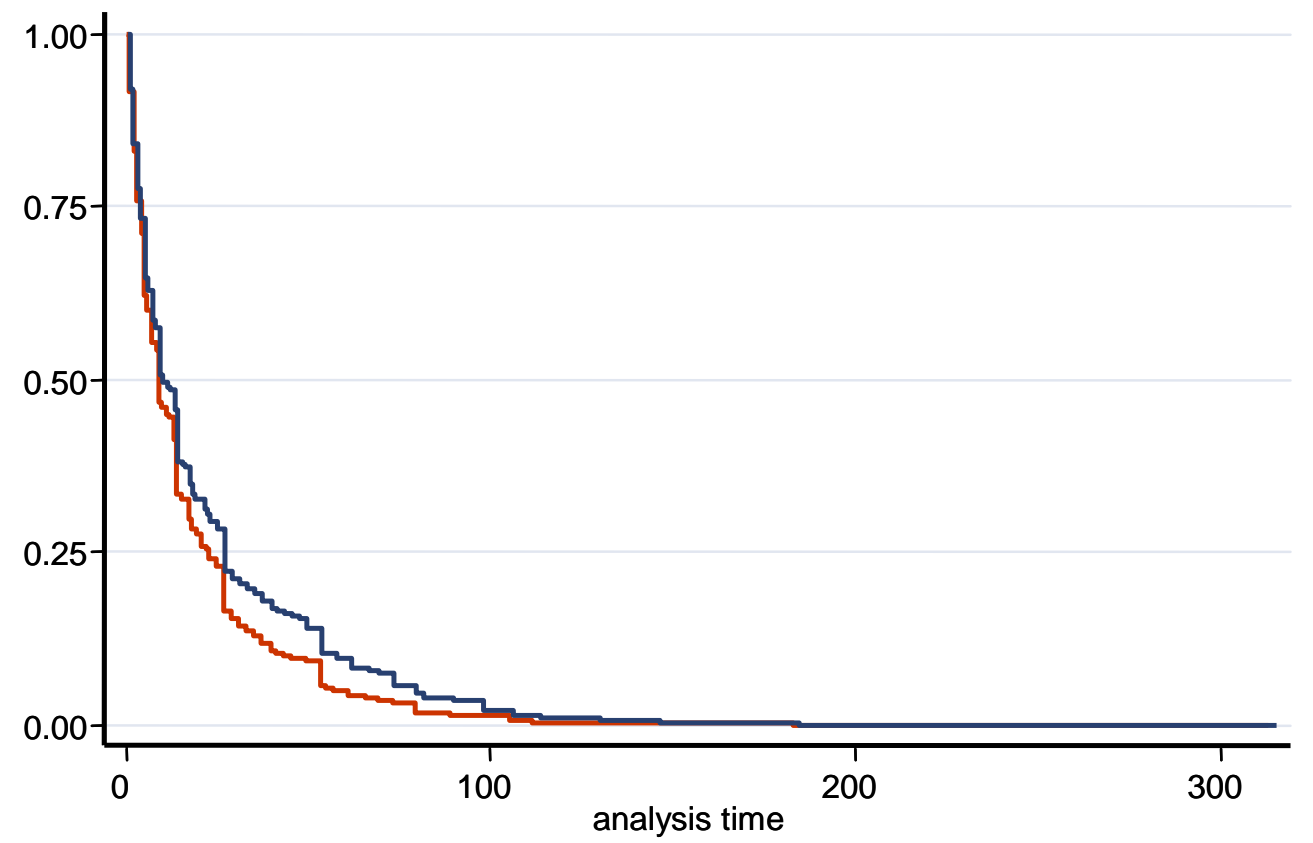

